\title{
Ligand specificity of Killer cell Immunoglobulin-like Receptors: a brief history of KIR
}

\author{
Jeroen van Bergen ${ }^{1 *}$ and John Trowsdale ${ }^{2}$ \\ Department of Immunohematology and Blood Transfusion, Leiden University Medical Center, Leiden, Netherlands \\ 2 Immunology Division, Department of Pathology, Cambridge University, Cambridge, UK \\ *Correspondence: j.van_bergen@lumc.nl
}

Edited by:

Eric Vivier, Centre d'Immunologie de Marseille-Luminy, France

Reviewed by:

Eric Vivier, Centre d'Immunologie de Marseille-Luminy, France

Natural Killer (NK) cells are a subset of innate lymphoid cells specialized for cytotoxicity and production of inflammatory cytokines such as IFN $\gamma$. As such, they are presumed to be important for early control of infections with intracellular pathogens and anti-tumor immunity. In addition, NK cells may help to regulate placentation. The activation of effector functions is controlled by the integration of signals from multiple receptors, including not only activating and inhibitory NK cell receptors but also receptors for cytokines such as IL-12, -15, -18. The Killer cell Immunoglobulin-like Receptors (KIR) make up the largest and by far most polymorphic human NK cell receptor family. Underscoring the importance of KIR, their genetic variation is associated with resistance to viruses such as HCV and HIV, autoimmune diseases and reproductive success. To understand how KIR influence health and reproduction, it is critical to know what molecules they interact with. In this topic, leading experts provide an up-to-date overview of the known ligand specificities of specific KIR.

Cresswell and deMars first showed in 1989 that transfection of HLA class I molecules into class I-deficient cell lines reduced their susceptibility to NK cell lysis (Harel-Bellan et al., 1986; Quillet et al., 1988; Shimizu and DeMars, 1989; Storkus et al., 1989). In this fashion, several HLA-B and -C alleles were identified as potential ligands for inhibitory NK cell receptors (Ciccone et al., 1992; Colonna et al., 1993; Cella et al., 1994; Mandelboim et al., 1996). Certain antibodies to NK cell surface molecules were able to restore lysis of these HLA class I transfectants by NK cell clones, allowing the definition of specificities of the receptors that were blocked by the antibodies. Most of the antibodies (GL183, EB6, CH-L, DX27, HP-3E4) bound $58 \mathrm{kDa}$ receptors for HLA-C variants characterized by either an Asparagine (C1) or a Lysine (C2) at position 80 of their alpha-chains (Ciccone et al., 1992; Moretta et al., 1993; Mandelboim et al., 1996), others (DX9, Z27) a $70 \mathrm{kDa}$ receptor for HLA-B (and some HLA-A) alleles carrying the "Bw4-motif" (Litwin et al., 1994; Gumperz et al., 1995), and a few $(\mathrm{Q} 66, \mathrm{DX} 31)$ bound a $140 \mathrm{kDa}$ homodimeric receptor for HLA-A3 and -A11 (Pende et al., 1996). In many individuals the antibodies recognizing inhibitory, $58 \mathrm{kDa}$ receptors for HLA$\mathrm{C}$ also bound $50 \mathrm{kDa}$ proteins from NK cell clones that acted as activating receptors. Some of these receptors also bound HLA-C, although weakly (Moretta et al., 1995).

Molecular cloning revealed that these receptors carried 1-3 immunoglobulin-like extracellular domains that were very similar between different receptors (Colonna and Samaridis, 1995; D'Andrea et al., 1995; Wagtmann et al., 1995). The main differences between activating and inhibitory receptors were found in their cytoplasmic tails. While the inhibitory receptors had a long cytoplasmic tail with two ITIMs, allowing inhibitory signaling (Burshtyn et al., 1996; Olcese et al., 1996), the activating ones had a short cytoplasmic tail and a positively charged residue in their transmembrane domain, allowing association with the ITAM-bearing, signaling adapter DAP12 (Olcese et al., 1997; Lanier et al., 1998). As scientists generally would rather share toothbrushes than nomenclatures, for a while nomenclatures from different laboratories co-existed. However, since the receptors from different loci had remarkably high sequence similarity, in some cases over $97 \%$, and clearly belonged to the same receptor family, it made sense to use a unified nomenclature that reflected the receptors' structures (Long et al., 1996). The receptors were named KIR. KIR2D $(50,58 \mathrm{kDa})$ and KIR3D $(70,140 \mathrm{kDa})$, refer to receptors with two or three IgSF domains, respectively. Furthermore, L stands for receptors having long and $S$ for those having short cytoplasmic tails, consistent with the presence or absence of ITIM motifs, respectively. Each KIR subfamily is designated by an individual number, for example KIR2DS1 (Uhrberg et al., 1997; Valiante et al., 1997). The different KIR loci can be found, together with discontinued names, on the EBI-website: http://www.ebi.ac.uk/ipd/kir/genes.html (Robinson et al., 2010).

Molecular cloning of the KIR paved the way for more detailed genetic analyses. In the first instance, novel KIR were cloned from cDNA libraries by homology. In this way KIR2DL4 (Selvakumar et al., 1996), a receptor for HLA-G (Rajagopalan and Long, 1999; Rajagopalan et al., 2005), was identified. The KIR locus, located on chromosome 19q13.4, turned out to be densely packed with KIR genes, oriented in a head-to-tail fashion (Martin et al., 2000; Wilson et al., 2000). While some KIR haplotypes contained few KIR genes, others had many. These efforts also revealed the existence of additional KIR genes KIR2DL5A, KIR2DL5B, KIR2DS5, KIR3DL3 (Vilches et al., 2000; Gomez-Lozano et al., 2002), as well as several pseudogenes (KIR2DP1, KIR3DP1, KIR1D). Common to virtually all haplotypes is the presence of KIR3DL3 at the centromeric end of the locus, KIR2DL4 roughly in the center, and KIR3DL2 at the telomeric end. It also quickly became clear that individual KIR genes display extensive and functional polymorphism (O'Connor et al., 2007). 
The total number of functional KIR genes is 15, and well over 50 alleles for individual genes have been described (http://www.ebi.ac.uk/ipd/kir/alleles.html).

All this sequence information allowed the design of primer sets to rapidly determine the presence or absence of specific KIR genes (or alleles) in individuals (Uhrberg et al., 1997), which in turn allowed genetic association studies. The first report of this kind showed that the presence of KIR2DS2 was associated with vasculitis in rheumatoid arthritis patients (Yen et al., 2001; Majorczyk et al., 2007). Subsequent studies indicated a role for KIR in psoriatric arthritis (Martin et al., 2002b; Nelson et al., 2004; Williams et al., 2005), type I diabetes (van der Slik et al., 2003, 2007) and several other auto-immune conditions. In line with the notion that NK cells are important mediators of antiviral immunity, variation in KIR genes associated with the ability to control infection with hepatitis C (Khakoo et al., 2004; Knapp et al., 2010; Dring et al., 2011) and HIV (Martin et al., 2002a, 2007). The largest studies of this kind showed epistatic interaction between KIR3DS1 and HLA-B in resistance to HIV progression (Martin et al., 2002a, 2007). Finally, interactions between maternal KIR and fetal HLA-C appeared to influence reproductive success (Hiby et al., 2004, 2010).

\section{REFERENCES}

Ahlenstiel, G., Martin, M. P., Gao, X., Carrington, M., and Rehermann, B. (2008). Distinct KIR/HLA compound genotypes affect the kinetics of human antiviral natural killer cell responses. J. Clin. Invest. 118, 1017-1026.

Alter, G., Martin, M. P., Teigen, N., Carr, W. H., Suscovich, T. J., Schneidewind, A., et al. (2007). Differential natural killer cellmediated inhibition of HIV-1 replication based on distinct KIR/HLA subtypes. J. Exp. Med. 204, 3027-3036.

Alter, G., Rihn, S., Walter, K., Nolting, A., Martin, M., Rosenberg, E. S., et al. (2009). HLA class I subtypedependent expansion of KIR3DS1+ and KIR3DL1+ NK cells during acute human immunodeficiency virus type 1 infection. J. Virol. 83, 6798-6805.

Anfossi, N., Andre, P., Guia, S., Falk, C. S., Roetynck, S., Stewart, C. A., et al. (2006). Human NK cell education by inhibitory receptors for MHC class I. Immunity 25, 331-342.

Boyington, J. C., Motyka, S. A., Schuck, P., Brooks, A. G., and Sun, P. D. (2000). Crystal structure of an NK cell immunoglobulinlike receptor in complex with its class I MHC ligand. Nature 405, 537-543.

Burshtyn, D. N., Scharenberg, A. M., Wagtmann, N., Rajagopalan, S., Berrada, K., Yi, T., et al. (1996).
Recruitment of tyrosine phosphatase HCP by the killer cell inhibitor receptor. Immunity 4 77-85.

Campbell, K. S., and Purdy, A. K. (2011). Structure/function of human killer cell immunoglobulinlike receptors: lessons from polymorphisms, evolution, crystal structures and mutations. Immunology 132, 315-325.

Cella, M., Longo, A., Ferrara, G. B., Strominger, J. L., and Colonna, M. (1994). NK3-specific natural killer cells are selectively inhibited by Bw4-positive HLA alleles with isoleucine 80. J. Exp. Med. 180, 1235-1242.

Ciccone, E., Pende, D., Viale, O., Than, A., di Donato, C., Orengo, A. M., et al. (1992). Involvement of HLA class I alleles in natural killer (NK) cell-specific functions: expression of HLA-Cw3 confers selective protection from lysis by alloreactive NK clones displaying a defined specificity (specificity 2). J. Exp. Med. 176, 963-971.

Cisneros, E., Moraru, M., GomezLozano, N., Lopez-Botet, M., and Vilches, C. (2012). KIR2DL5: an orphan inhibitory receptor displaying complex patterns of polymorphism and expression. Front. Immunol. 3:289. doi: 10.3389/fimmu.2012.00289

Colonna, M., Borsellino, G., Falco, M., Ferrara, G. B., and Strominger, J. L. (1993). HLA-C is the inhibitory ligand that determines dominant

Even though these studies demonstrated an important role for KIR and KIR-HLA interactions in various diseases, the underlying mechanisms are only beginning to be understood (Anfossi et al., 2006; Alter et al., 2007, 2009; Ahlenstiel et al., 2008; Hiby et al., 2010; O'Connor et al., 2011; Tarek et al., 2012). A critical gap in our knowledge is the fact that ligands for many activating, and some inhibitory, KIR are unknown. Of the eight inhibitory KIR, five have well-characterized HLA specificities. Generally, KIR2DL1, KIR2DL2, KIR2DL3 together cover all HLA-C alleles, KIR3DL1 binds a subset of HLA-B alleles, and KIR3DL2 binds HLA-A3/A11 loaded with specific peptides as well as homodimers of HLA-B27 heavy chains. These binding profiles are supported in some cases by structural studies (Boyington et al., 2000; Fan et al., 2001; Campbell and Purdy, 2011; Vivian et al., 2011). Of the six activating KIR, only KIR2DS1 has a clearly defined specificity: C2 (Stewart et al., 2005). In this topic, leading experts discuss the state of the art in ligand identity for several KIR, in an effort to shed light on the contribution of KIR-ligand interactions to disease (Cisneros et al., 2012; Korner and Altfeld, 2012; Moesta and Parham, 2012; Rajagopalan and Long, 2012; Shaw and Kollnberger, 2012).

resistance to lysis by NK1- and NK2-specific natural killer cells. Proc. Natl. Acad. Sci. U.S.A. 90, 12000-12004.

Colonna, M., and Samaridis, J. (1995). Cloning of immunoglobulinsuperfamily members associated with HLA-C and HLA-B recognition by human natural killer cells. Science 268, 405-408.

D’Andrea, A., Chang, C., Franz-Bacon, K., McClanahan, T., Phillips, J. H., and Lanier, L. L. (1995). Molecular cloning of NKB1. A natural killer cell receptor for HLA-B allotypes. J. Immunol. 155, 2306-2310.

Dring, M. M., Morrison, M. H., McSharry, B. P., Guinan, K. J., Hagan, R., O'Farrelly, C., et al. (2011). Innate immune genes synergize to predict increased risk of chronic disease in hepatitis $\mathrm{C}$ virus infection. Proc. Natl. Acad. Sci. U.S.A. 108, 5736-5741.

Fan, Q. R., Long, E. O., and Wiley, D. C. (2001). Crystal structure of the human natural killer cell inhibitory receptor KIR2DL1-HLACw4 complex. Nat. Immunol. 2, $452-460$.

Gomez-Lozano, N., Gardiner, C. M., Parham, P., and Vilches, C. (2002). Some human KIR haplotypes contain two KIR2DL5 genes: KIR2DL5A and KIR2DL5B. Immunogenetics 54, 314-319.

Gumperz, J. E., Litwin, V., Phillips, J. H., Lanier, L. L., and Parham, P.
(1995). The Bw4 public epitope of HLA-B molecules confers reactivity with natural killer cell clones that express NKB1, a putative HLA receptor. J. Exp. Med. 181, 1133-1144.

Harel-Bellan, A., Quillet, A., Marchiol, C., DeMars, R., Tursz, T., and Fradelizi, D. (1986). Natural killer susceptibility of human cells may be regulated by genes in the HLA region on chromosome 6 . Proc. Natl. Acad. Sci. U.S.A. 83, 5688-5692.

Hiby, S. E., Apps, R., Sharkey, A. M., Farrell, L. E., Gardner, L., Mulder, A., et al. (2010). Maternal activating KIRs protect against human reproductive failure mediated by fetal HLA-C2. J. Clin. Invest. 120, 4102-4110.

Hiby, S. E., Walker, J. J., O’Shaughnessy, K. M., Redman, C. W., Carrington, M., Trowsdale, J., et al. (2004). Combinations of maternal KIR and fetal HLA-C genes influence the risk of preeclampsia and reproductive success. J. Exp. Med. 200, 957-965.

Khakoo, S. I., Thio, C. L., Martin, M. P., Brooks, C. R., Gao, X., Astemborski, J., et al. (2004). HLA and NK cell inhibitory receptor genes in resolving hepatitis $\mathrm{C}$ virus infection. Science 305, 872-874.

Knapp, S., Warshow, U., Hegazy, D., Brackenbury, L., Guha, I. N., Fowell, A., et al. (2010). Consistent beneficial effects of killer cell immunoglobulin-like receptor 
2DL3 and group 1 human leukocyte antigen-C following exposure to hepatitis C virus. Hepatology 51, 1168-1175.

Korner, C., and Altfeld, M. (2012). Role of KIR3DS1 in human diseases. Front. Immunol. 3:326. doi: 10.3389/fimmu.2012.00326

Lanier, L. L., Corliss, B. C., Wu, J., Leong, C., and Phillips, J. H. (1998). Immunoreceptor DAP12 bearing a tyrosine-based activation motif is involved in activating NK cells. Nature 391, 703-707.

Litwin, V., Gumperz, J., Parham, P., Phillips, J. H., and Lanier, L. L. (1994). NKB1: a natural killer cell receptor involved in the recognition of polymorphic HLA-B molecules. J. Exp. Med. 180, 537-543.

Long, E. O., Colonna, M., and Lanier, L. L. (1996). Inhibitory MHC class I receptors on $\mathrm{NK}$ and $\mathrm{T}$ cells: a standard nomenclature. Immunol. Today 17, 100 .

Majorczyk, E., Pawlik, A., Luszczek, W., Nowak, I., Wisniewski, A., Jasek, M., et al. (2007). Associations of killer cell immunoglobulin-like receptor genes with complications of rheumatoid arthritis. Genes Immun. 8, 678-683.

Mandelboim, O., Reyburn, H. T., ValesGomez, M., Pazmany, L., Colonna, M., Borsellino, G., et al. (1996). Protection from lysis by natural killer cells of group 1 and 2 specificity is mediated by residue 80 in human histocompatibility leukocyte antigen $\mathrm{C}$ alleles and also occurs with empty major histocompatibility complex molecules. J. Exp. Med. 184, 913-922.

Martin, A. M., Freitas, E. M., Witt, C. S., and Christiansen, F. T. (2000). The genomic organization and evolution of the natural killer immunoglobulin-like receptor (KIR) gene cluster. Immunogenetics 51, 268-280.

Martin, M. P., Gao, X., Lee, J. H., Nelson, G. W., Detels, R., Goedert, J. J., et al. (2002a). Epistatic interaction between KIR3DS1 and HLA-B delays the progression to AIDS. Nat. Genet. 31, 429-434.

Martin, M. P., Nelson, G., Lee, J. H., Pellett, F., Gao, X., Wade, J., et al. (2002b). Cutting edge: susceptibility to psoriatic arthritis: influence of activating killer Ig-like receptor genes in the absence of specific HLA-C alleles. J. Immunol. 169, 2818-2822.

Martin, M. P., Qi, Y., Gao, X., Yamada, E., Martin, J. N., Pereyra, F., et al.
(2007). Innate partnership of HLA-B and KIR3DL1 subtypes against HIV-1. Nat. Genet. 39, 733-740.

Moesta, A. K., and Parham, P. (2012). Diverse functionality among NK cell receptors for the $\mathrm{C} 1$ epitope of HLA-C: KIR2DS2, KIR2DL2, and KIR2DL3. Front. Immunol. 3:336 doi: 10.3389/fimmu.2012.00336

Moretta, A., Sivori, S., Vitale, M., Pende, D., Morelli, L., Augugliaro, R., et al. (1995). Existence of both inhibitory (p58) and activatory ( $\mathrm{p} 50$ ) receptors for HLA-C molecules in human natural killer cells. J. Exp. Med. 182, 875-884.

Moretta, A., Vitale, M., Bottino, C., Orengo, A. M., Morelli, L. Augugliaro, R., et al. (1993). P58 molecules as putative receptors for major histocompatibility complex (MHC) class I molecules in human natural killer (NK) cells. Anti-p58 antibodies reconstitute lysis of MHC class I-protected cells in NK clones displaying different specificities. J. Exp. Med. 178, 597-604.

Nelson, G. W., Martin, M. P., Gladman, D., Wade, J., Trowsdale, J., and Carrington, M. (2004). Cutting edge: heterozygote advantage in autoimmune disease: hierarchy of protection/susceptibility conferred by HLA and killer Ig-like receptor combinations in psoriatic arthritis. J. Immunol. 173, 4273-4276.

O'Connor, G. M., Guinan, K. J., Cunningham, R. T., Middleton, D. Parham, P., and Gardiner, C. M. (2007). Functional polymorphism of the KIR3DL1/S1 receptor on human NK cells. J. Immunol. 178, 235-241.

O'Connor, G. M., Yamada, E., Rampersaud, A., Thomas, R. Carrington, M., and McVicar, D. W. (2011). Analysis of binding

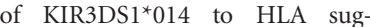
gests distinct evolutionary history of KIR3DS1. J. Immunol. 187, 2162-2171.

Olcese, L., Cambiaggi, A., Semenzato, G., Bottino, C., Moretta, A., and Vivier, E. (1997). Human killer cell activatory receptors for MHC class I molecules are included in a multimeric complex expressed by natural killer cells. J. Immunol. 158, 5083-5086.

Olcese, L., Lang, P., Vely, F., Cambiaggi, A., Marguet, D., Blery, M., et al. (1996). Human and mouse killercell inhibitory receptors recruit PTP1C and PTP1D protein tyrosine phosphatases. J. Immunol. 156, 4531-4534.
Pende, D., Biassoni, R., Cantoni, C. Verdiani, S., Falco, M., di Donato, C., et al. (1996). The natural killer cell receptor specific for HLA-A allotypes: a novel member of the p58/p70 family of inhibitory receptors that is characterized by three immunoglobulin-like domains and is expressed as a $140-\mathrm{kD}$ disulphidelinked dimer. J. Exp. Med. 184 505-518.

Quillet, A., Presse, F., MarchiolFournigault, C., Harel-Bellan, A. Benbunan, M., Ploegh, H., et al. (1988). Increased resistance to non-MHC-restricted cytotoxicity related to HLA A, B expression. Direct demonstration using beta 2-microglobulin-transfected Daudi cells. J. Immunol. 141, 17-20.

Rajagopalan, S., Bryceson, Y. T., Kuppusamy, S. P., Geraghty, D. E., Meer, A. V., Joosten, I., et al. (2005). Activation of NK cells by an endocytosed receptor for soluble HLA-G. PLoS Biol. 4:e9. doi: 10.1371/journal.pbio.0040009

Rajagopalan, S., and Long, E. O. (1999). A human histocompatibility leukocyte antigen (HLA)-G-specific receptor expressed on all natural killer cells. J. Exp. Med. 189, 1093-1100.

Rajagopalan, S., and Long, E. O. (2012). KIR2DL4 (CD158d): an activation receptor for HLAG. Front. Immunol. 3:258. doi: 10.3389/fimmu.2012.00258

Robinson, J., Mistry, K., McWilliam, H., Lopez, R., and Marsh, S. G. (2010). IPD-the immuno polymorphism database. Nucleic Acids Res. 38, D863-D869.

Selvakumar, A., Steffens, U., and Dupont, B. (1996). NK cell receptor gene of the KIR family with two IG domains but highest homology to KIR receptors with three IG domains. Tissue Antigens 48, 285-294.

Shaw, J., and Kollnberger, S. (2012). New perspectives on the ligands and function of the killer cell immunoglobulin-like receptor KIR3DL2 in health and disease. Front. Immunol. 3:339. doi 10.3389/fimmu.2012.00339

Shimizu, Y., and DeMars, R. (1989). Demonstration by class I gene transfer that reduced susceptibility of human cells to natural killer cellmediated lysis is inversely correlated with HLA class I antigen expression. Eur. J. Immunol. 19, 447-451.

Stewart, C. A., Laugier-Anfossi, F., Vely, F., Saulquin, X., Riedmuller J., Tisserant, A., et al. (2005).
Recognition of peptide-MHC class I complexes by activating killer immunoglobulin-like receptors. Proc. Natl. Acad. Sci. U.S.A. 102, 13224-13229.

Storkus, W. J., Alexander, J., Payne, J. A., Dawson, J. R., and Cresswell, P. (1989). Reversal of natural killing susceptibility in target cells expressing transfected class I HLA genes. Proc. Natl. Acad. Sci. U.S.A. 86, 2361-2364.

Tarek, N., Le Luduec, J. B., Gallagher, M. M., Zheng, J., Venstrom, J M., Chamberlain, E., et al. (2012). Unlicensed NK cells target neuroblastoma following anti-GD2 antibody treatment. J. Clin. Invest. 122, 3260-3270.

Uhrberg, M., Valiante, N. M., Shum, B. P., Shilling, H. G., LienertWeidenbach, K., Corliss, B., et al. (1997). Human diversity in killer cell inhibitory receptor genes. Immunity 7 , 753-763.

Valiante, N. M., Uhrberg, M., Shilling, H. G., Lienert-Weidenbach, K., Arnett, K. L., D'Andrea, A., et al. (1997). Functionally and structurally distinct NK cell receptor repertoires in the peripheral blood of two human donors. Immunity 7 739-751.

van der Slik, A. R., Alizadeh, B. Z., Koeleman, B. P., Roep, B. O., and Giphart, M. J. (2007). Modelling KIR-HLA genotype disparities in type 1 diabetes. Tissue Antigens 69(Suppl. 1), 101-105.

van der Slik, A. R., Koeleman, B. P., Verduijn, W., Bruining, G. J. Roep, B. O., and Giphart, M. J. (2003). KIR in type 1 diabetes: disparate distribution of activating and inhibitory natural killer cell receptors in patients versus HLAmatched control subjects. Diabetes 52, 2639-2642.

Vilches, C., Rajalingam, R., Uhrberg, M., Gardiner, C. M., Young, N. T., and Parham, P. (2000). KIR2DL5, a novel killer-cell receptor with a D0-D2 configuration of Iglike domains. J. Immunol. 164 5797-5804.

Vivian, J. P., Duncan, R. C., Berry, R., O'Connor, G. M., Reid, H H., Beddoe, T., et al. (2011). Killer cell immunoglobulinlike receptor 3DL1-mediated recognition of human leukocyte antigen B. Nature 479, 401-405.

Wagtmann, N., Biassoni, R., Cantoni, C., Verdiani, S., Malnati, M. S., Vitale, M., et al. (1995). Molecular clones of the p58 NK cell receptor reveal immunoglobulin-related 
molecules with diversity in both the extra- and intracellular domains. Immunity 2, 439-449.

Williams, F., Meenagh, A., Sleator, C., Cook, D., Fernandez-Vina, M., Bowcock, A. M., et al. (2005). Activating killer cell immunoglobulin-like receptor gene KIR2DS1 is associated with psoriatic arthritis. Hum. Immunol. 66, 836-841.
Wilson, M. J., Torkar, M., Haude, A., Milne, S., Jones, T., Sheer, D., et al. (2000). Plasticity in the organization and sequences of human KIR/ILT gene families. Proc. Natl. Acad. Sci. U.S.A. 97, 4778-4783.

Yen, J. H., Moore, B. E., Nakajima, T., Scholl, D., Schaid, D. J., Weyand, C. M., et al. (2001). Major histocompatibility complex class I-recognizing receptors are disease risk genes in rheumatoid arthritis. J. Exp. Med. 193, 1159-1167.

Received: 28 November 2012; accepted: 06 December 2012; published online: 24 December 2012.

Citation: van Bergen $J$ and Trowsdale $J$ (2012) Ligand specificity of Killer cell Immunoglobulin-like Receptors: a brief history of KIR. Front. Immun. 3:394. doi: 10.3389/fimmu.2012.00394
This article was submitted to Frontiers in NK Cell Biology, a specialty of Frontiers in Immunology.

Copyright (c) 2012 van Bergen and Trowsdale. This is an open-access article distributed under the terms of the Creative Commons Attribution License, which permits use, distribution and reproduction in other forums, provided the original authors and source are credited and subject to any copyright notices concerning any third-party graphics etc. 